\title{
ARTICLES
}

\section{EXTREMISM, TERRORISM AND ISLAM: HISTORICAL AND CONTEMPORARY PERSPECTIVES}

\author{
Mohammad Hashim Kamali*
}

\begin{abstract}
A conceptual characterisation of extremism at the outset is followed by an outline of its principal indicators and types, such as the fanatic pursuit of one particular view. The extremist tends to be self-righteous, power-hungry, willing to inflict harm and hardship on others, and also inclined to conflate the order of values. Then follows an exposition of the varieties of extremism and a review also of the Islamic sources concerning them. There are references in this connection to Arab Spring, ISIS, Boko Haram and Charlie Hebdo, and then a review of expert opinion, policy scenarios and responses to extremism and terror. The article concludes with a set of actionable recommendations.
\end{abstract}

\section{Meaning and Scope of Extremism}

Extremism is usually self-evident and easily identifiable for the most part, but it may require further scrutiny in technical and contextualised situations. Killing another person is an extreme behaviour, yet if it is done in the context of self-defence that repels an overwhelming and instantaneous attack on one's life, it would not be considered extreme. This contextualised and relative aspect of extremism also becomes evident by reference to strong political currents and sets of circumstances with the results, for instance, that one person's extremism becomes another person's moderation, and the freedom fighter of one becomes the terrorist of another and so forth. Gay marriage gains legal recognition under one set of values and is considered an abomination in another. This would suggest the need for one to know moderation and normality, and the source of authority and values they refer to in order to be able to identify when they are violated by extremist behaviour. Extremist behaviour in technical subjects would not be self-evident to a lay person, and would need specialised input to enable a credible assessment. Extremism is usually definitive and deliberate, yet it can also be due to ignorance and error of judgment, especially in technical matters that require specialised know-how. ${ }^{1}$ 
Extremism is the conceptual opposite of moderation and almost as extensive in that it just about relates to every subject of concern to moderation. Whereas moderation is centripetal and strongly tends toward the centre, extremism is centrifugal that pushes away from the centre toward the outer edges and extremes of its subject matter. Extremism violates the limits of moderation. These limits can often be identified by reference to authoritative sources and documents, such as laws and constitutions, religious scriptures, such as the Qur'an and hadith, moral standards and the general mores and customs of society. But since world religions and philosophies, as well as the mores and customs of societies, and the values they uphold or deny, tend to differ widely, what may one consider to be extremist or moderate under one is also likely to vary accordingly under another code of values.

Like moderation, extremism also applies to the entire spectrum of values, good and bad, positive and negative. One can be extremist in what may be deemed as virtuous, such as measure for measure justice that verges on literalism and severity in the application of rules and in treating, for instance, recidivists and first time offenders under the same rules without consideration of the differentials. Similarly, continuous fasting even outside the month of Ramadan, and all night vigil, such that may damage one's health and family life would amount to extremism in religiosity.

One can also be extremist in pursuit of one's rights and liberties, as in the case of freedom of expression when used so as to offend others - almost all the provocative cartoons of the Prophet of Islam by some Danish and French publishers illustrate this. One may have the right to just retaliation, even revenge under due process, but it can be taken to excess for what may be a minor provocation, as in the case of Israeli retaliatory attacks against Palestinian rocket fire. Extremism in the interpretation of ideas can be illustrated by the Islamic militant group ISIS's interpretation of the Islamic caliphate and so forth.

The clash-of-civilisations narrative found credible manifestations in the 9/11 attacks and the numerous other instances of terrorism, military aggression and violence that followed and brought Islam increasingly into the focus of world attenton. Experts and media pundits often saw Islam as the sole explanation of extremism among Muslims. Too often, Islam is portrayed negatively and monolithically as a growing threat to world peace, obscuring the diversity of opinions within Islam and the fact that most Muslims condemn extremism and violence. Expert opinion reviewed in the following paragraphs indicates that a great deal of extremist behaviour among Muslims is reactive and related to military aggression and humiliating violence by superior military powers. Unlike the common perception that connects extremism with religion, closer scrutiny 
reveals that religion has a minimal role and that most of the causes of extremism are extraneous to religion.

Muslims the world over do not see the mainstream media depictions of Islam as a true portrayal of their religion, rather they see a total contrast between these and their own image of moderation that characterised Islamic civilisation. Muslims view Islam as a religion that values truth and justice, and shuns laxity on one side and extremism on the other. There is no denial on the other hand that extremism existed, in varying degrees, among Muslims, as among other communities and traditions, almost everywhere and at any given time. Yet the Muslim world has evidently been witnessing an escalation of extremism and violence in recent years. Even the rosy promise of the Arab Spring when it first began, yielded to extremism across swathes of West Asia and North Africa.

Extremism has not, however, commanded a credible majority in Muslim societies. Extremists are usually small groups of people that advocate narrow and radical views and ideologies. They are not able to persuade and influence the majority through rational debate, which is why they usually take to the street and resort to violent methods to buttress their claims. Extremists are also groups of people who allege that they are championing the cause of justice and correct wrongs resulting from the conduct of others. Extremism may also be a reaction against the leadership of a country or in opposition to a dominant ideology. The larger than real presence of extremism is felt due to views and claims clamorously expressed, and actions taken boldly beyond the ordinary, done in order to attract attention or merely to gain sympathy. While such daring extremists and desperate tactics shock society, they are short-lived and ultimately self-defeating. ${ }^{2}$

\section{Hallmarks of Types of Extremism}

One of the first markers of extremism is fanatic advocacy of one view or opinion and ignoring others, even though the person knows of the existence of other views. This kind of fanaticism is in a state of denial to all else, including that which may be in the public interest and in harmony with the objectives of the religion he follows. This denial also extends to the prevailing conditions of time and place, dialogue and search for balanced and well-moderated solutions. The extremist even does not stop at mere denial but goes on to accuse others of ignorance and transgression, especially those do who not follow his or her views.

The extremists also tend to be certain of the correctness of their cause so much so that they focus clearly and project unequivocal positions. They have a black and white view of their purpose that helps create certainty in an uncertain world. That also explains why they possess an ability to attract attention disproportionate to their numbers or percentage in any given population. By contrast, the moderates 
tend to be reflective, see nuances and rarely exhibit certainty of that kind. Extremists tend to triumph not because of their inherent strength but more often because of the weakness and hesitancy of moderates.

Furthermore, the extremists turn a blind eye to the needs and wishes of others and show eagerness to impose harsh and taxing demands on them. They are prone to ignoring people's weaknesses and refuse to acknowledge that some people may be weak, in poor health and unprepared to comply with their demands. ${ }^{3}$

The extremists are also inclined to confuse the essential with the subsidiary. One learns from a perusal of the Qur'an and guidelines of Sunnah of the existence of a certain order of priorities wherein emphasis is placed on essentials, and observance of subsidiary requirements is treated with a lighter touch and less emphasis. The Qur'anic guideline on this is found in the following verse: "If you avoid the most heinous of the prohibited conduct, We shall conceal all your sins and admit you to a gate of great honour" (al-Nisa', 4:31).

The verse clearly conveys the message that avoidance of major sins can by itself act as a concealer of the minor ones a person may have committed.

Al-Qaradawi recounts, in this connection, instances where the Prophet of Islam turned a blind eye to the misgivings of certain individuals even if they only did the bare minimum of obligatory duties and added little or nothing else by way of supererogatory practices of the religion. ${ }^{4}$ To be overemphatic on every detail can be exhaustive and demanding and can also distract attention from that which is essential.

Reflecting on Islamic history, three varieties of extremist activities are distinguishable: theological, political, and practical - even though they are not always mutually exclusive of one another.

Theological extremism (al-tatarruf al-i tiq $\bar{a} d \bar{l}$ ) is noticeable when the extremist subscribes to particular beliefs that stand in conflict with the clear text of the Qur'an, authentic hadith, and general consensus (ijma') of Muslims. ${ }^{5}$ A reference is made in this connection to early theological movements that arose in the first two centuries of Islam, such as the Qadariyyah, the Jahmiyyah, the Murji'ah, and Batiniyyah as explained below.

The Qadariyyah (advocates of free will or qadar) subscribed to the view that man is the sole creator of his own conduct. The Jahmiyyah (followers of Jahm bin Safwan) subscribed to total predestination; the Murji' ah (suspenders of judgment and upholders permanently of hope or rija') suspended passing any judgment on sinners. They also include those who held extremist views concerning the Companions of the Prophet Muhammad - going as far as to charge some of the prominent Companions with infidelity and kufr. ${ }^{6}$ The Batiniyyah (esotericists also known as Isma'iliyyah, a Shi' ite sub-sect) held that every overt speech and word of God in the Qur'an had a hidden meaning known only to their Imam. 
To these may be added perhaps the ghulat (extremists) of Shi 'a as well as some of the contemporary movements that include the Takfir and Hijrah Association (Jamā'ät al-takfir wa'l-hijrah) of Egypt, which charged the Egyptian state with infidelity that had allegedly turned into Dar al-Kufr (abode of unbelief). It was a duty therefore of Muslims to leave that country and emigrate. ${ }^{7}$

Political extremism (al-tatarruf al-siyasi) is marked by confrontation and challenge of the authority of a lawful government. Noted in this category are the Kharijites (lit. outsiders) who emerged in Iraq and boycotted the authority of the fourth caliph 'Ali Ibn Abu Talib, as well as declaring permissible the killing of all Muslims except for their own followers. ${ }^{8}$ The Kharijites held the extremist view that committing a major sin amounts to a renunciation of Islam. One of the Kharijites factions, namely the Azariqah, further added that a person renounces Islam even if he committed a major sin by error or personal interpretation and ijtihād, which is why they charged the caliph 'Ali with infidelity over the issue of Arbitration (tahkim). For the Caliph had exercised his own ijtihād in that matter. The Caliph was charged with infidelity for the mere fact of his agreeing to arbitration between him and his challenger, the then governor of Sham, Mu'awiyah b. Abu Sufyan. ${ }^{9}$

Lastly, practical extremism (al-tațarruf al- 'amalī) that consists of extremist conduct, such as self-immolation, excessive fasting and all-night vigil, renouncing marriage and acts that depart from sound human nature (fitrah), valid Sunnah and precedent of the Prophet. One may add to these such other instances of practical extremism as excessive dieting to keep slim, especially among younger women, excessively disciplinarian practices with one's children and the like, which are injurious and harmful.

Terrorism is also practical extremism, be it local, national or international, in peacetime or war that consists mainly of acts of terror and violence, bombing and use of explosives that kill innocent people and cause destruction. Such activities may even occur in the course of a legitimate war that may have been duly declared by the lawful leader. The basic position of such acts of terror is the same in Shari'ah whether its victims are Muslim or otherwise, and whether it is against a weak, or a more powerful party or state. ${ }^{10}$ Terrorism may have different causes that may, on that basis, be classified under one or the other variety of extremism mentioned above.

As we watch the so-called Islamic State group, ISIS, fighters rampaging through the Middle East, the tearing apart of states and cities and massacres of innocent civilians, it may be difficult to believe we are living in the twenty first century. The sight of terrified refugees and indiscriminate violence is all too reminiscent of Crusaders and the Mongol hordes of Genghis Khan. The ferocious cruelty of these militants, that of the Taliban in Afghanistan, and Boko Haram in 
Nigeria, the Charlie Hebdo attacks in Paris etc., raise a distinctly modern concern over the connection between religion and violence.

Global security, safety and well-being of people are also jeopardised in laws of some Muslim countries that violate citizen and human rights with impunity and uphold religious beliefs by force. ISIS is a product of decades of "failed governance in the Arab world and Pakistan." 11 The radicalisation of Muslim youth within Western societies that turn them against the common values and ideals of their new domicile, and extremism that spreads like a cancer in failed states are among the previously unknown manifestations of extremism we are witnessing in increasing proportions. State-sponsored terrorism is no less a manifestation of extremism than actions by non-state actors and may, indeed, even be the direct cause that provokes retaliation by non-state actors. Media estimates mention that one-third of the ISIS forces are foreign, including hundreds, even thousands, of young Muslims from France, Belgium, Britain and other countries of Europe. Some are hardline jihadists, but many are just losers, misfits and adventure seekers. The hardline elements of Taliban in Afghanistan and Pakistan who are not satisfied with the more moderate Muslims among them, plus the fact that the Taliban have generally become weak, are beginning to align themselves with ISIS. Media reports indicate that some of these new followers may have already started carrying the black banner of ISIS as their rallying point. ${ }^{12}$

The other one-third of ISIS is made up of former Sunni Ba'thist army officers, Iraqi Sunnis and tribesmen; for many Sunni villagers under ISIS control, ISIS is just less bad than how they were treated by Iraq's previous Shi 'ah-led government. The remaining one-third of ISIS is composed of true ideologues, led by Abu Bakr al-Baghdadi, who have their own apocalyptic version of Islam. The New York Times columnist Thomas Friedman maintains that this version of Islam would not be resonating so forcefully were it not for the fact that "both religion and politics have been hijacked" in the Arab world and Pakistan. ${ }^{13}$ The Arab peoples have been mostly ruled by radicals and reactionaries. Without the prospect of legitimate politics that genuinely responds to popular grievances, no amount of top-down attempts to engender a moderate version of Islam will succeed. Islam has no Vatican to decree whose Islam is authentic, so it emerges differently in different contexts. ${ }^{14}$

Governments in both Muslim and non-Muslim countries are taking note of the need to work more closely with community partners, religious institutions, education centres and the media to create an anti-extremist current of opinion and environment. With reference to Malaysia, among the factors prompting young Muslims to undertake these dangerous assignments of travel to Syria, one is "the lack of basic religious fundamentals, which cause them to be easily influenced by extremist teachings." Furthermore, the "West is seen as an enemy of the 
Muslims; and the Muslim community at the international level is seen to have failed to protect the oppressed Muslim countries," which has in turn caused these individuals to join the ISIS militant group. ${ }^{15}$

Social media also plays a role in enabling the extremists to spread their message with the rapidity that was not possible before. While saying this, Asri Zainul Abidin, Mufti of the northern state of Perlis, Malaysia, also commented that by "invading and bombing Muslim countries, the US and its Western allies have engendered a sense of despair in Muslims worldwide ... Disappointed with their own governments for corruption and injustice along with anger at the US has made them look for solutions elsewhere." When they hear of ISIS, they are led to believe that it's a revival of the Caliphate during Islam's Golden Age. ${ }^{16}$ The Mufti further added that Caliphate was certainly not meant to perpetuate violence and warfare like what the ISIS is doing. The Caliphate's aim was to establish good governance, instill Islam with a positive message for the rest of the world, and most of all to uphold justice. ${ }^{17}$

Those who commit cowardly murder behind a mask of "Islam" and imagine they are taking revenge and waging jihad are in fact, in the eyes of the true Islam, murderers. It is despicable to hunt down defenceless people and shoot them in a vicious act of terror simply because they think wrongly, or insult or are hostile to Islam. ${ }^{18}$

Protection of life (hifz al-nafs) - of all human life - is one of the overriding goals and purposes (maqasid) of Islam and the Shari'ah. Human life must be safeguarded as a matter of priority. "One who saves the life of another," says the Qur'an, "it would be as if he saves the life of the whole of humankind" (alMa'idah, 5:35). The text also declares in the same verse: "And one who kills a human being without the latter being guilty of murder or corruption in the land, it would be as if he has killed the whole of humankind." Elsewhere the Qur'an enjoins: "Slay not the life which Allah has made sacrosanct unless it be in the cause of justice" (al-Isra', 17:33). These passages capture well the increased inter-dependency of human security in the age of globalisation. To say that the slaying of one human is tantamount to an attack on the sanctity of human life generally is the essence of the threat humanity is now facing.

Al-Bukhari and Muslim, the two most authoritative collections of hadith, have recorded the following hadiths from the Prophet: "One who raises arms against us ceases to be one of us;", 19 and a rehash of the same in another hadith in the same chapter and source: "One who unsheathes his sword against us is not one of us." 20

In yet another hadith, it is provided: "All that belongs to a Muslim is forbidden to other Muslims; his blood, his property and his honour."21

Terrorising innocent people that may or may not lead to loss of life and limb constitutes the crime of hirabah, which carries the death punishment by the clear 
text of the Qur'an (5:33). The prohibition of hirabah in this text is conveyed in general and unqualified terms that subsume individuals, groups, state and nonstate parties all alike.

\section{Terrorism: Changing Trajectories and Fresh Appraisals}

Judging by the scale of violence in recent years in Afghanistan, Iraq, Syria, Palestine, Pakistan and elsewhere, Muslims are themselves the principal victims of violence in the name of religion. The victims of crude brutality and indiscriminate drone attacks are also defenceless Muslim civilians, women and children for the most part. In a revealing interview published in January 2013 in Foreign Affairs, retired General Stanley McChrystal said about counterterrorism:

Americans have got to understand that if we were to use our technological capabilities carelessly - I don't think we do, but there is always the danger that you will - then we should not be upset when someone responds with their equivalent, which is a suicide bomb in Central park, because that's what they can respond with. ${ }^{22}$

The ugly truism flies in our faces that violence begets violence; that militarism is itself a problem, not a solution. The unprecedented violence and terror attacks the world is witnessing is also not all religious - oppression, discrimination, humiliation, socio-economic factors, exaggerations and provocative media all come into the picture. Religion is also not the primary cause of violence in any of the countries mentioned, although it is being used and abused in so many ways that hardly need elaboration.

Local and regional dynamics that propel terrorism tend to differ in Europe, America, the Middle East and Afghanistan, although this does not rule out similarities between them in certain areas. Europe and the US tend to have one feature in common, for instance: Islamophobia. There are literally hundreds of websites, radio programmes and TV networks that specialise in anti-Islam propaganda. The twitter hashtag \#killall-Moslem has been around since 2011. While this abundance of offensiveness may comfort those concerned about freedom of expression, "it does not give me any comfort," wrote Sami Mahroum, "as a European Muslim." ${ }^{23}$

Europe's Muslims are by and large peaceful. There are no real home-grown Islamic terrorist organisations of any significance in Europe. Almost all terrorist acts in Europe are the works of a single umbrella organisation - al-Qaeda. Western spy agencies are also widely suspected to be involved in provocative and tension generating assignments. Yet it is comforting to know that violent ideology has very limited appeal among the Muslims of Europe. Radicalised European Muslims 
must look elsewhere for support. Sami Mahroum added the information that in late 2014, the Mayor of Sarge-leslie Man's, a French town of about 3,500 people with 180 Muslim students, sought to impose pork meat on all schools. A couple of years earlier, the then French president Nicolas Sarkozy joined in a campaign to ban halal meat branding, which became an election issue. The Swiss meanwhile, have banned minarets. The list goes on. ${ }^{24}$

Following the Charlie Hebdo attacks in Paris, United States Senator John McCain told New York Times on how to stop this from happening on the US soil next: It would require a more aggressive American military strategy across the greater Middle East, with ground troops and no-fly zone in Syria and more troops in Iraq and Afghanistan. Fareed Zakaria who quoted McCain followed on with his own assessment: This theory was sometimes described in the Iraq War as 'We fight them there, so we don't have to fight them here.' "It was wrong then and it is wrong now." ${ }^{25}$ Zakaria added that intervention has, on the contrary, been the cause of a great deal of suicide bombings and violent attacks in recent years. In this connection, he referred to a CNN report that back in 2007, Cherif Kouachi, one of the Paris terrorists, revealed the source of his radicalisation. "I was ready to go and die in battle. I got this idea when I saw the injustices shown by television on what was going on over there (in Iraq). I am speaking about the torture that the Americans have inflicted on the Iraqis." Zakaria went on to quote the scholars Robert Pape and James Feldman, who analysed all of the more than 2,100 documented cases of suicide bombings from 1980 to 2009 and concluded that the vast majority of the perpetrators were acting in response to American intervention in the Middle East rather that out of a religious or ideological motivation. When people are attacked they invariably become extreme. But only a tiny proportion of the Muslim respondents in a Gallup poll actually agreed with terrorism: 93 per cent answered 'no' to the Gallup poll whether the 9/11 attacks were justified. ${ }^{26}$ The reasons that drive the terrorists vary from a sense of adventure to radicalism and total despair, but battling a foreign (Western) intervention is often high on the list. Another scholar Zakaria has quoted in support of his own assessment is Andrew Bacevich, who pointed out that before Syria, Washington had already launched interventions in thirteen countries in the Islamic world since 1980. Will one more really do the trick? ${ }^{27}$

In answer to an interview question "are terrorists primarily traumatized?" Karen Armstrong said that some of them are and some of them are plain wicked. Osama bin Laden "was a plain criminal." But there is also great fear and despair among them. ${ }^{28}$ Armstrong then recounts that surveys have been done by forensic psychiatrists who interviewed people convicted of terrorism since 9/11. They interviewed hundreds of people in Guantanamo and other prisons. And one forensic psychiatrist, who is also an officer of the CIA, concluded that Islam had 
nothing to do with it. The problem was "rather ignorance of Islam. Had they had a proper Muslim education they wouldn't be doing this. Only 20\% of them has had a regular Muslim upbringing. The rest are either new converts - like the gunmen who recently attacked the Canadian Parliament; or non-observant, which means that they don't go to the mosque - like the bombers in the Boston Marathon; or self-taught. Two young men who left Britain to join the jihad in Syria ordered from Amazon a book called Islam for Dummies. "That says it, you see." 29

The unqualified condemnation that Muslim religious and political notables have expressed against the ISIS and Charlie Hebdo atrocities and similar acts of despicable terror is to be welcomed. Muslim leaders, international organisations and fatwa councils, including the Majlis Ulama Indonesia, the National Fatwa Council of Malaysia, and the Mufti of Saudi Arabia, denounced the brutality and violence of the ISIS group as violating the core principles of Islam. This line of condemnation from Muslim quarters also became evident within days of the Charlie Hebdo attacks.

Condemnation alone will not, however, address the causes of such heinous violence, which in the case of ISIS is the political mess, power vacuum and failure of good governance in Syria and Iraq, where states failed and social order collapsed. Angry and disillusioned men and women, Shi'ah, Sunni, Kurds and others feel that the path of violence is the only one left for them to take. ${ }^{30}$

Prolonged dictatorship in the Arab world has spawned extremist (mostly religious) opposition movements. The more repressive the regime, the more extreme the opposition. Islam became the language of opposition because it was a language that could not be shut down or censored. Now, the old Arab order is crumbling, but it has led to instability which created new opportunities for militant and extremist groups. ${ }^{31}$ Unless the root causes of radical extremism are addressed, many have warned that extremism is likely to be on the rise. Once a radical group falls by the wayside, discredited or irrelevant, another, often more radical and violent emerges. This is what ISIS is to al-Qaeda by upping the stake in the radicalisation contest and becoming even more destructive and violent than its predecessor. ${ }^{32}$

When modern Middle Eastern terrorism first appeared on the scene in the 1960s and 1970s, the historian David Fromkin wrote in an essay in Foreign Affairs that from its very beginnings, after the French Revolution, terrorism has been a strategy of the weak, designed to project false strength and, above all, make onlookers miscalculate. Fromkin provided examples, one of which referred to a meeting in 1945 with a leader of the Irgun, a group of about 1,500 Jewish militants in Palestine, which was then part of the British empire. ${ }^{33}$

The Irgun knew they could not defeat the mighty British army, so they decided to blow up buildings and create the appearance of chaos. The Irgun leader said 
that this would lead the British to overreact, garrison and militarise the empire that would, in turn, strain British resources to the point that it may eventually decide to leave Palestine. Seeing that it was too small to defeat Great Britain, the Irgun decided as an alternative approach that "Britain was big enough to defeat itself." 34

While quoting Fromkin, Fareed Zakaria commented that the ISIS strategy in many ways resembles that of the Irgun. The targeting of America and its allies, the videos and the barbarism are all designed to draw Washington into a ground battle in Syria and a protracted war that would sap the superpower's strength. The conclusion is then drawn: "though terrorism cannot always be prevented, it can always be defeated. You can always refuse to do what they want you to do." 35

In an interview following the launch of her new book, Fields of Blood, Religion and the History of Violence, Karen Armstrong, whom we already mentioned, was expressive of her feelings to say that "I am filled with a sense of dread as to where we are going." We have created bombs that can wipe out the world, and it is accepted in international law that if your nation is threatened it is acceptable to fire off a nuclear weapon. It won't be long before Al-Qaeda or one of these groups gets hold of a nuclear device. "The situation is so dangerous that we are forced to open our eyes and see what's going on. And that is not about religion, Islam or otherwise." ${ }^{36}$ To the suicide bomber who goes in with explosives knowing that he will die, it matters little whether the explosives that kill him are conventional or nuclear!

Razali Ismail, the former Malaysian envoy at the UN and President of UNGA, observed that contrary to the warning that "power corrupts, and absolute power corrupts absolutely," extremism is not caused singularly by unrestrained power. Rather, it is caused by the over-zealous promotion of one view, one approach and one thought to the exclusion of all else. Long before extremism can congeal in the form of terrorist groups, rogue states and ultra-violent social configurations, each of these bodies have acquired an orthodoxy that resists any form of intellectual challenge, changes of time and circumstance. ${ }^{37}$

Lisette Thooft who had read Karen Armstrong's new book, Fields of Blood, said at one point "reading the (500 page) book I realised: what a river of blood and tears is running through our world history." To this, Armstrong commented: "And misery and oppression, and injustice. Great injustice and we are still unjust. Because we talk about our Enlightenment as if the Messiah came down ... And it was great. It was very important for us. ${ }^{.38}$ But look at the founding fathers of the United States, who said that all men are created equal: they had no problem owning African slaves. Liberty was only ever for Europeans. "And it is still like that, because of the greed for oil. We give huge support to the Saudis, who give their people no human rights." ${ }^{\prime 39}$ 
It is also well to remember, as Paridah Samad points out, the December 1983 meeting between the US secretary of defence Donald Rumsfeld and the dictator Saddam Hussein, which was designed to emphasise America's "close relationship" with Iraq as an ally. ${ }^{40}$ In a similar vein, the US championed Egypt's Husni Mubarak before demanding his arrest, and tolerated Pakistan's General Ziaul-Haq, who helped Talibanise Pakistan, and then of course invaded Afghanistan, a country that had no involvement in the $9 / 11$ attacks. ${ }^{41}$

Extremism is also a co-traveller of the power-hungry, one that denies others their due in total pursuit of one's own interests. The problem is not always a lack of formula for a reasonable solution to a contentious issue, but refusal to accede to an obvious solution. This is the problem of one party's preference for the winner-takes-all option, as in the case of Israel, that generates belligerence - the very reason also for Palestine to burn on a regular basis. Given a huge imbalance of power and continuous reinforcement of Israeli military power by the United States and Israel's refusal to budge from its one-directional policy of occupation, expansion and oppression, the prospects of peace in the Middle East are bound to remain elusive. ${ }^{42}$

Rabbi Mark Winer wrote in a 2012 article "Fundamentalists versus Moderates" that the future of humanity may well depend on the ability of moderates within each religion to overcome their extremist co-religionists. It would appear, he added, that extremism spawns interfaith bigotry and sanctions violence, war and terrorism. In the twentieth century, more people died in the name of religion than in all of history before. There is a real fear that the twenty-first century may even eclipse the grisly record for interfaith bigotry and terrorism of the previous century. A great deal therefore depends upon our understanding of the eternal conflict between extremism and moderation, and upon the strategies the religious moderates devise together to combat their common scourge. ${ }^{43}$ It is indicative of the wisdom of the early pioneers of Islam who called the Kharijites (Khawarij, lit. outsiders) by this name, and made it known from early on that this group has exited itself from the mainstream community of Muslims. They have the choice to change their behaviour and rejoin the community or else to stay as outsiders. The same can be said of ghulat (lit. exaggerators), the name so unmistakeably expressive of its purpose, that was given to a small group of Shi ites who exaggerated in their interpretations of the doctrine of imamate so as to elevate the first Shi' ite Imam, 'Ali ibn Abu Talib, to a deity. There should be no doubt that massacre and mayhem can never be accepted in the name of Islam, and we need to be vigilant and decisive on criminality of the kind that has become so frequent and keeps putting the good name of Islam and vast majority of peaceable Muslims on the line.

In combating terrorism, states and societies need to be firm and decisive, of 
course, but they must not let the terrorists get what they want. An early indication of this could be noted in what President Francois Hollande of France, and the German Chancellor, Angela Merkel, said in their speeches following the Paris killings. Speaking at the Arab World Institute in Paris, President Hollande said: "It is Muslims who are victims of fanaticism, fundamentalism and intolerance," adding that the Muslim community in France, Europe's largest, had "the same rights and same duties as all citizens" and must be protected. The German Chancellor in her speech at the Bundestag declared her country's unity with France, adding the remark that Islam was not the cause; rather it was extremism that was the common enemy. ${ }^{44}$

At a time when the self-styled Patriotic Europeans Against the Islamisation of the Occident, or Pegida, were planning several rallies in various German cities following the Paris attacks, Chancellor Merkel went on record to say that "Islam belongs to Germany ... I am the chancellor of all Germans." She also announced she would join a Muslim community rally in Berlin against extremism along with her ministers, to be followed by attending a vigil at Berlin's iconic Brandenburg Gate, organised by the Central Council of Muslims in Germany under the banner "Let's be there for each other, Terror: not in our names." Merkel thanked the leaders of four-million-strong Muslim community for "quickly and clearly condemning the violence committed in the name of their faith." ${ }^{45}$

Timely efforts by the Muslims of Germany and Merkel's announcement seem to have had a calming effect on curbing the prospects of further unrest in the country. It was also not accidental to see media reports that revulsion with "Pegida's xenophobic message" had sparked growing counter demonstrations and rallies, which helped to dwarf the anti-foreigner movement and "its regional clones." ${ }^{46}$ The World Economic Forum in Davos 2015 also followed in close succession, where the U.S Secretary of State, John Kerry, made a statement on 13 January 2015 that extremists who are killing children and others in Iraq, Syria, Nigeria and other parts of the world may cite Islam as a justification, but the West should be careful about calling them "Islamic radicals." He added that it would be a mistake to link Islam to criminal conduct that was rooted in "alienation, poverty, thrill-seeking and other factors ... The biggest error we could make would be to blame Muslims for crimes ... that their faith utterly rejects." Kerry's message resonated in fact what President Obama had earlier said in a September 2014 speech that "No religion condones the killing of innocents and the vast majority of the Islamic State's victims have been Muslims." ${ }^{\text {47 }}$ Then also at the National Prayer Breakfast in Washington DC in the first week of February 2015, when Obama went on record to say: "Christians have been equally guilty of such atrocities. We are no better that Islamic State. Remember that during the Crusades, people committed terrible deeds in the name of Christ." 
These are encouraging signs, indicative perhaps of a change of policy by Western leaders that could have beneficial effects. For juxtaposing Islam with terrorism, as had hitherto been the case in mainstream media, only had the effect of aligning the vast majority of peaceable Muslims with the terrorists - forcing some perhaps to take up common causes with them. There is now an acknowledgment that much of the Muslim unrest in Europe had been related to equality and antidiscrimination issues rather than religious provocations. If there were instances of religious unrest at the early stages of the cartoon episodes, that phase seems to have passed and European Muslims may be having fresh perspectives over issues, and have consequently become more proactive and quick to join hands with the anti-terrorist campaign.

One can hardly think that anyone could soil Islam's name so badly as the likes of ISIS, Boko Haram and Charlie Hebdo attackers. If there be enough realisation of this among the extremists, when they are convinced that they are doing more harm than good to the cause of their religion, "as Islamic leaders all over the world are already pointing out, their numbers will eventually diminish." ${ }^{48}$ Scott Thompson who made this remark also observed that "the Paris terrorists are not to be taken as representatives of Islam. Thousands of Islamic groups and convocations have joined the outrage and made clear ... that such actions are contrary to the nature and central teachings of the Prophet." ${ }^{\prime 49}$

\section{Conclusion and Recommendations}

Our review of the concept and types of extremism in the Islamic sources was followed, in this article, by an examination of expert opinion and policy scenarios that offered insights on how to understand and address issues in their proper context. We also learned that terrorism is not confined by reference to geographical, religious or cultural divides. It is global in that no country or community is immune to the growing menace of global terrorism. Then it would follow that countries and communities need to join hands, design and plan common strategies and solutions to fight extremism and terror if the hope for a peaceful world were to become a realistic prospect.

I conclude with the following recommendations:

- When dealing with instances of violent extremism, states and security forces should avoid the trap of reacting to violence with greater violence. Should they respond in that manner, it would lead to a situation where the terrorists have won an even greater victory, for the whole country would then be in a state of constant fear.

- Advocacy of public welfare, job creation, poverty eradication efforts, protection of the rights and dignity of all citizens and good governance may well be the main solutions to nullify the strongest magnet of extremism in 
the Muslim world. This is all the more important in pluralist societies where people of different persuasions need to stand together for the common good, advocate the values of moderation and take a common stand on combating extremism.

- To defeat ISIS and not to see another emerge in its place, it is necessary to expose the mendacity of its ideas and enlist Muslims' concerted effort to discredit the extremist interpretations of Islam.

- We learn from the wisdom of the pioneers of Islam who declared their purpose so clearly when they named the Kharijites and the Ghulat extremists by these names. Our political leaders, scholars and ulama should emulate them by identifying and excommunicating the terrorists at an early stage and indeed every opportunity when they address their constituencies and audience.

- Collective actions and strategies at national and international levels are called for to stem the injustice, corruption and sectarianism now rampant in much of the Arab world and Pakistan. With regard to the Arab-Israeli conflict, which is the most pervasive, the conflicting parties should recognise each other's legitimate concerns - Palestine's right to selfdetermination, return of the occupied lands, and cessation of Settlement building - and Israel's concern for recognition and assurances of peace with its neighbours, and cessation of rocket fire. Without these and perhaps other confidence-building measures, no amount of negotiation is likely to bring lasting peace to the Middle East.

- The Sunnis of Iraq should be enabled to carve out their own autonomous region and a share of the national oil wealth similar perhaps to that the Kurds of Iraq in the Kurdistan province.

- Afghanistan's peace efforts and on-going negotiations with the Taliban with China's mediation should be encouraged to lead to the signing of a peace pact by the concerned parties. Pakistan's constructive participation should also be encouraged with the hope that China's presence will provide an assurance of Pakistan's proactive policy stance for the future of peace in Afghanistan.

Needless to say that those who offend in the name of freedom of expression and do more of the same in the wake of painful incidents of provocation and violence, as in the case of the satirical Charlie Hebdo publishers printing millions of additional copies with offending depictions of Prophet Muhammad, they are certainly not helping the cause of peace or freedom. For if that is what freedom of expression must mean, then whoever advocates it is putting his credibility in question, and with it also the peace and security of his own community and people. 
They have a cause for reflection and should take note perhaps of what President Hollande and Chancellor Merkel did, which was to show sensitivity and concern not to inflame situations any further. To do otherwise benefits probably no one, but if one were to name a beneficiary, then it would most likely be the terrorists.

\section{Notes}

* Mohammad Hashim Kamali, Founding CEO of IAIS Malaysia, graduated from Kabul University, and took his $\mathrm{PhD}$ in Islamic and Middle Eastern Law at the University of London in 1969. Professor Dr M. H. Kamali served as Professor of Islamic Law and Jurisprudence at the International Islamic University Malaysia (IIUM, 19852007), then Dean of the International Institute of Islamic Thought and Civilization (ISTAC). He also held Visiting Professorships at McGill University's Institute of Islamic Studies; Capital University, Ohio; and the Wissenschaftskolleg, Berlin. A member of the Constitution Review Commission of Afghanistan (2003), he has provided expert legal consultation to the new constitutions of Iraq, the Maldives and Somalia. Eminent authority on Islamic legal studies, he has published over 170 academic articles and 35 texts, including standard textbooks at universities worldwide. He can be contacted at ceo@iais.org.my.

1. In the context of the Air Asia Indonesia crash that killed all of its 162 passengers and crews on 28 December 2014, the black box data showed that in the final four minutes before the aircraft crashed into the sea, it had started climbing very steeply at the rate of over 1,800 meters per minute, which is far in excess of the 300 to 600 meters for passenger aircraft - only a fighter jet can climb at that speed. This was identified as the main cause of the crash. This may be said to be extremist behaviour in that situation, which is somewhat specialised and the relevant information is such that the layman would normally not know. It may also have been due to ignorance or an error of judgment on the part of the pilot.

2. Cf., Zainal Ujang, "High hopes on Farhan," (Ujang, currently a fellow at the Oxford Centre for Islamic Studies, U.K - wrote this comment in anticipation of a public lecture Farhan Nizami the Director of that Centre was due to deliver in Kuala Lumpur), Kuala Lumpur: New Straits Times, May 26, 2014, p. 17.

3. Yusuf Al-Qaradawi,"Min al-Ghuluww wa'-Inhilal ila-Wasatiyyah wa'l-I' idal," in Mu'assasah Aal al-Bayt al-Islami, Mustaqbal al-Islam fi'l-Qarn al-Hijri al-Thamin al- 'Ashr, Jordan: Amman, 1425/2004, pp. 303-4.

4. Ibid., p. 304.

5. Wahbah Al-Zuhaylī, "al-Tatarruf fi'l-Islam," in Mu'assasah Aal al-Bayt al-Islami, Mustaqbal al-Islām fi'l-Qarn al-Hijri al-Khamis 'Ashr, Jordan: Amman, 1425/2004, p. 205.

6. The Murji' ah were divided into in two groups, one suspended passing any judgment on differences that arose among the Companions referring them to God's judgment, and the second group, which held that God forgives all sins except disbelief (kufr) and that faith is not obliterated by sin. See for details al- Zuhaylī in the previous note. See also Majid Fakhry, "Philosophy and Theology," in John Esposito (ed.), The Oxford History of Islam (Oxford: Oxford University Press, 1999), $277 \mathrm{ff}$. 
7. Al-Zuhaylī, "al-Tatarruf fi'l-Islam," 205. Hadi Abu Talib who also wrote on the subject of extremism (al-tațarruf) in the same collection of essays where Zuhaylī's article appears, considers hasty pronouncements of infidelity and kufr by those who wrongfully lay this charge against others as a manifestations of religious extremism (al-tațarruf al-dīnì). See for details 'Abd al-Hadi Abu Talib, "al-Tațarruf al-Dīnī wa Wasatiyyat al-Islām," in Mu'assasah Aal al-Bayt, Mustaqbal al-Islām, pp. 185-6.

8. Cf., Muhammad 'Abd al-Latif Al-Farfur, Al-Wasatiyyah fi'l-Islām, Amman: Dar alNafa'is, 1988, p. 94.

9. See for details Al-Farfur, al-Wasatiyyah fi'l-Islām, p. 94.

10. Al-Zuhaylī, “al-Tatarruf fi'l-Islam,”, p. 208.

11. Thomas L. Friedman, "Defeating IS with moderation," Kuala Lumpur, New Straits Times, March 2, 2015, p. 15.

12. Paridah Abd Samad, "The Muslim Dilemma in France," Kuala Lumpur, New Straits Times, January 10, 2015, p. 14.

13. Thomas L. Friedman, "Defeating IS with moderation," p. 15.

14. Ibid.

15. Bernard Cheah, "Why Malaysians willing to join IS," Kuala Lumpur, The Sun, December 18, 2014, p. 2.

16. "Perlis mufti speaks his mind on IS," Mohd Asri Zainal Abidin interviewed by with Choong Boon Siew, Kuala Lumpur, The Sun, March 18, 2015, p. 7.

17. Ibid.

18. Cf., Harun Yahya, “Getting Islam's peaceful ethos across amidst terror," Kuala Lumpur, New Straits Times, January 16, 2015, p. 17.

19. Muslim, Mukhtasar Sahih Muslim, ed. Muammad Nasir al-Din al-Albani, K. alImarah, bab. man hamala 'alayna al-silaha, hadith 1235.

20. This second hadith is narrated on the authority of Salamah ibn al-Akwa' whereas the first on the authority of 'Abd Allah ibn 'Umar. Both are reliable.

21. Muhyiddin al-Nawawi, Riyad al-Salihin, $2^{\text {nd }}$ ed. by Muhammad Nasir al-Din alAlbani, Beirut: Dar al-Maktab al-Islami, 1418/1998, hadith 1527.

22. Quoted in Fareed Zakaria "Keep calm and carry on to effectively fight terror," Kuala Lumpur, New Straits Times, January 24, p.16.

23. Sami Mahroum, "Charlie Hebdo and the anti-Muslim media factory," Kuala Lumpur, New Straits Times, January 19, 2015, p. 17.

24. Ibid.

25. Fareed Zakaria, "US intervention is not the answer," Kuala Lumpur, New Straits Times, January 19, 2015, p. 15.

26. Several Gallup polls post $9 / 11$ confirm that one's religious affiliation has little relevance to one's view of violence. www.gallup.com/poll/157067/views-violence. aspx (accessed 23 March 2015).

27. Ibid.

28. Karen Armstrong: "There is nothing in the Islam that is more violent than Christianity," interviewed by Lisette Thooft, http:/www.nieuwwij.nl/english/karen-armstrongnothing-islam-violent-christianity/ 18 January 2015 at p. 3 (accessed 19 March 2015).

29. Ibid, p.4.

30. Amnesty International, Escape from Hell: Torture and Sexual Slavery in Islamic State Captivity in Iraq, United Kingdom: Amnesty International Ltd., 2014.

31. Cf., Fareed Zakaria, "Keep calm and carry on to effectively fight terror," Kuala 
Lumpur, New Straits Times, January 24, p. 16.

32. Cf., Farish Noor, "Radicalism's pool of support," Kuala Lumpur: New Straits Times, August 25, 2014, p. 12.

33. David Fromkin as quoted by Fareed Zakaria in "Denying Islamic State what it wants," Kuala Lumpur, New Straits Times, February 7, 2015, p. 16.

34. Ibid.

35. Ibid.

36. Karen Armstrong: "There is nothing in the Islam," p. 4.

37. Razali Ismail, "Moderation must be ubiquitous," Kuala Lumpur, New Straits Times, January 7 2012, p. 28.

38. Karen Armstrong: "There is nothing in the Islam," p. 3.

39. Ibid.

40. Paridah Abd Samad, "A president's campaign Against the American ego," Kuala Lumpur, New Straits Times, February 10, 2015, p. 15.

41. Ibid.

42. Cf., New Straits Times Editorial page on 'Malaysia's strategy for peace,' Kuala Lumpur, November 28, 2012, p. 14.

43. Rabbi Mark L. Winer, "Fundamentalists vs. Moderates: The War within Judaism," Arches Quarterly, vol. 5, no. 9 (Spring 2012), p. 117.

44. "Hollande: Muslims the victims," AFP report carried in Kuala Lumpur, New Straits Times, January 16, 2015, p. 25. The present writer personally watched both leaders shown on BBC World Service evening news on 15 January 2015.

45. AFP report from Dresden, "Germany slams anti-Islamic March," Kuala Lumpur, New Straits Times, January 14, 2015, p. 26.

46. Ibid.

47. Quoted in Paridah Abd Samad "A president's campaign," as in fn. 40 above, p. 15.

48. Scott Thompson, "Liberty's 9/11," Kuala Lumpur, New Straits Times, January 14, 2015, p. 17.

49. Ibid. 